\title{
On the use of a three-dimensional method in solving the U-Pb two-stage model
}

\author{
YONG-FeI ZHENG \\ Geochemisches Institut, Universität Göttingen, \\ Goldschmidtstr. 1, 3400 Göttingen, FRG \\ (Received April 11, 1989; Accepted May 24, 1989)
}

\begin{abstract}
The three-dimensional method is described for treating U-Pb isotopic data obeying a two-stage evolution. The $\mathrm{U}-\mathrm{Pb}$ discordia plane model and the $\mathrm{Pb}-\mathrm{Pb}$ isochron plane model are developed respectively, to eliminate the effect of the unknown common lead correction. Calculation formulae of best-fit plane parameters are given and some examples from the literature are recalculated to demonstrate the applicability of the method. The plane-fitting can be a convenient means in $\mathrm{U}-\mathrm{Pb}$ dating.
\end{abstract}

\section{INTRODUCTION}

The decay of the naturally occuring isotopes of uranium to lead gives rise to two independent geochronometers. When the uraniferous mineral or rock sample being dated has remained closed to uranium and all of its daughters and when appropriate corrections are made for the lead incorporated into the sample at the time of its formation, the two geochronometers should give concordant dates. However, discordant ages have often been observed ever since establishement of the $\mathrm{U}-\mathrm{Pb}$ dating method. Usually it is attributed to lead loss (although it can also be due to uranium gain). The episodic U-Pb models have been suggested by Wetherill (1956) and Gale and Mussett (1973) to decipher such a puzzle. Normally a suite of cogenetic samples are analysed and the results are presented on a concordia diagram where the ${ }^{236} \mathrm{~Pb}^{*} /{ }^{238} \mathrm{U}$ ratio is plotted versus the ${ }^{207} \mathrm{~Pb}^{*} /{ }^{235} \mathrm{U}$ ratio (Wetherill, 1956) or on a modified concordia diagram where the ${ }^{207} \mathrm{~Pb}^{*} /{ }^{206} \mathrm{~Pb}^{*}$ ratio is plotted versus the ${ }^{238} \mathrm{U} /{ }^{206} \mathrm{~Pb}^{*}$ ratio (Tera and Wasserburg, 1972). In this way, a two-stage model can be solved to yield two ages $t_{1}$ and $t_{2}$ responsible for-two episodic events. However, the superscript asterisk in the diagrams indicates that the radiogenic lead component only has to be used, i.e., the common ${ }^{206} \mathrm{~Pb}$ and ${ }^{207} \mathrm{~Pb}$ have to be substracted, which can be done only when the ${ }^{206} \mathrm{~Pb} /{ }^{204} \mathrm{~Pb}$ and ${ }^{207} \mathrm{~Pb} /{ }^{204} \mathrm{~Pb}$ ratios of the common lead in the sample suite are known.

A knowledge of the isotopic ratios of common lead is of crucial importance for an exact determination of the radiogenic lead dates, especially when the proportional of the common lead in the sample is large (Ludwig et al., 1985). These can be obtained from other minerals which are syngenetic and contain no uranium. However, these prerequisites are not always present. To eliminate the effect of the unknown common lead correction a three-dimensional discordia plane model has been developed by Wendt (1984) based on the modified discordia equation to solve the two-stage model using the directly measured isotopic ratios ${ }^{238} \mathrm{U} /{ }^{206} \mathrm{~Pb},{ }^{207} \mathrm{~Pb} /{ }^{206} \mathrm{~Pb}$ and ${ }^{204} \mathrm{~Pb} /{ }^{206} \mathrm{~Pb}$. This method assumes that all of the samples contain common lead of the same isotopic composition. Furthermore, it requires that the true $\mathrm{U}-\mathrm{Pb}$ apparent ages are variably discordant. It can display all the isotopic information about concordancy and common lead, or discordancy and intersection ages $t_{1}$ and $t_{2}$, without a correction for the common lead. Nonetheless, its derivation and calculating pro- 
cedure appear to be somewhat sophisticated so that it is not easy for it to be adopted by geochronologists who do not have a good mathematical background. In order to elucidate various aspects of the three-dimensional U-Pb data presentation, another two forms of plane solution of the U-Pb two-stage model are described in the present paper in the light of the $\mathrm{Pb}-\mathrm{Pb}$ isochron diagram and the concordia diagram. The present derivation seems easier to understand for a computation.

\section{U-Pb Discordia Plane Model}

According to the discordia equation (Wetherill, 1956) the concentrations of the radiogenic lead isotopes are linearly related to their parent isotopes in the concordia diagram:

$$
\frac{{ }^{206} \mathrm{~Pb}^{*}}{{ }^{238} \mathrm{U}}=\frac{{ }^{207} \mathrm{~Pb}^{*}}{{ }^{235} \mathrm{U}} a_{1}+a_{2}
$$

in which

$$
\begin{aligned}
& a_{1}=\frac{\exp \lambda t_{1}-\exp \lambda t_{2}}{\exp \lambda t_{1}-\exp \lambda^{\prime} t_{2}} \\
& a_{2}=\left(\exp \lambda t_{2}-1\right)-a_{1}\left(\exp \lambda^{\prime} t_{2}-1\right) .
\end{aligned}
$$

Where $\lambda$ and $\lambda^{\prime}$ are the decay constants of ${ }^{238} U$ and ${ }^{235} \mathrm{U}$, respectively. Within the framework of the two-stage model, Eq. (1) can be rewritten as:

$$
\frac{{ }^{206} \mathrm{~Pb}_{\mathrm{p}}}{{ }^{238} \mathrm{U}}-\frac{{ }^{206} \mathrm{~Pb}_{\mathrm{i}}}{{ }^{238} \mathrm{U}}=a_{1}\left(\frac{{ }^{207} \mathrm{~Pb}_{\mathrm{p}}}{{ }^{235} \mathrm{U}}-\frac{{ }^{207} \mathrm{~Pb}_{\mathrm{i}}}{{ }^{235} \mathrm{U}}\right)+a_{2}
$$

where the subscripts $p$ and $i$ denote the presentday and initial, respectively. After introducing the present-day ${ }^{238} \mathrm{U} /{ }^{204} \mathrm{~Pb}$ ratio into Eq. (4) we obtain the following plane equation:

$$
\left(\frac{{ }^{206} \mathrm{~Pb}}{{ }^{238} \mathrm{U}}\right)_{\mathrm{p}}=a_{1}\left(\frac{{ }^{207} \mathrm{~Pb}}{{ }^{235} \mathrm{U}}\right)_{\mathrm{p}}+a_{2}+a_{3} /\left(\frac{{ }^{238} \mathrm{U}}{{ }^{204} \mathrm{~Pb}}\right)_{\mathrm{p}}
$$

in which

$$
a_{3}=\left(\frac{{ }^{206} \mathrm{~Pb}}{{ }^{204} \mathrm{~Pb}}\right)_{\mathrm{i}}-137.88 a_{1}\left(\frac{{ }^{207} \mathrm{~Pb}}{204 \mathrm{~Pb}}\right)_{\mathrm{i}}
$$

Eq. (5) was essentially obtained by Levchenkov and Shukolyukov (1970). The quantities $\left({ }^{206} \mathrm{~Pb} /{ }^{238} \mathrm{U}\right)_{\mathrm{p}},\left({ }^{207} \mathrm{~Pb} /{ }^{235} \mathrm{U}\right)_{\mathrm{p}}$ and $\left({ }^{238} \mathrm{U} /{ }^{204} \mathrm{~Pb}\right)_{\mathrm{p}}$ can be experimentally determined for a suite of samples. These quantities can then be used to fit the parameters $a_{1}, a_{2}$ and $a_{3}$ in terms of the least squares method of fitting data points to a plane (see Appendix), provided that the U-Pb isotopic data from the analysed samples have experienced the following two-stage evolution:

(1) The lead evolved in an environment with a given $\mathrm{U} / \mathrm{Pb}$ ratio until a time $t_{1}$. At time $t_{1}$ the initial system became closed and was homogeneous with respect both to the $\mathrm{U} / \mathrm{Pb}$ ratio and to the isotopic composition of each element.

(2) Since time $t_{1}$ the system evolved only by the decay of uranium into lead, remaining closed and homogeneous until a time $t_{2}$.

(3) At time $t_{2}$ a brief differentiation took place within the closed system, altering the $\mathrm{U} / \mathrm{Pb}$ ratio from place to place within the system (without any isotopic fractionation of either lead or uranium) and thus dividing the grand system into a number of subsystems. Each subsystem is characterized by the quantity $\left({ }^{238} \mathrm{U} /{ }^{204} \mathrm{~Pb}\right)_{\mathrm{p}}$.

(4) From $t_{2}$ to the present, evolution again proceeds only by the decay of uranium, each subsystem remaining homogeneous and closed within itself, at least as far as uranium and lead are concerned. The specimens selected for analysis will, for this strictly two-stage evolution, be a direct sample of the whole set of subsystems.

In this context, the uranium has been differentiated two times relative to the lead in their evolutional history. But the most important point is that isotopic signatures of the initial (common) lead and the radiogenic lead from $t_{1}$ to $t_{2}$ have not been obliterated after the two episodic events in the analysed specimens.

When the numerical values of $a_{1}$ and $a_{2}$ are known, one can find $t_{2}$ at first through Eq. (3) and then $t_{1}$ through Eq. (2). In this way, both $t_{1}$ and $t_{2}$ can be simultaneously obtained from the experimentally measured $\mathrm{U}-\mathrm{Pb}$ isotopic data without a correction for the common lead. The goodness of fit of data points to the plane equation can be expressed as polycorrelation coefficient $R$ (see Appendix), which can serve as 


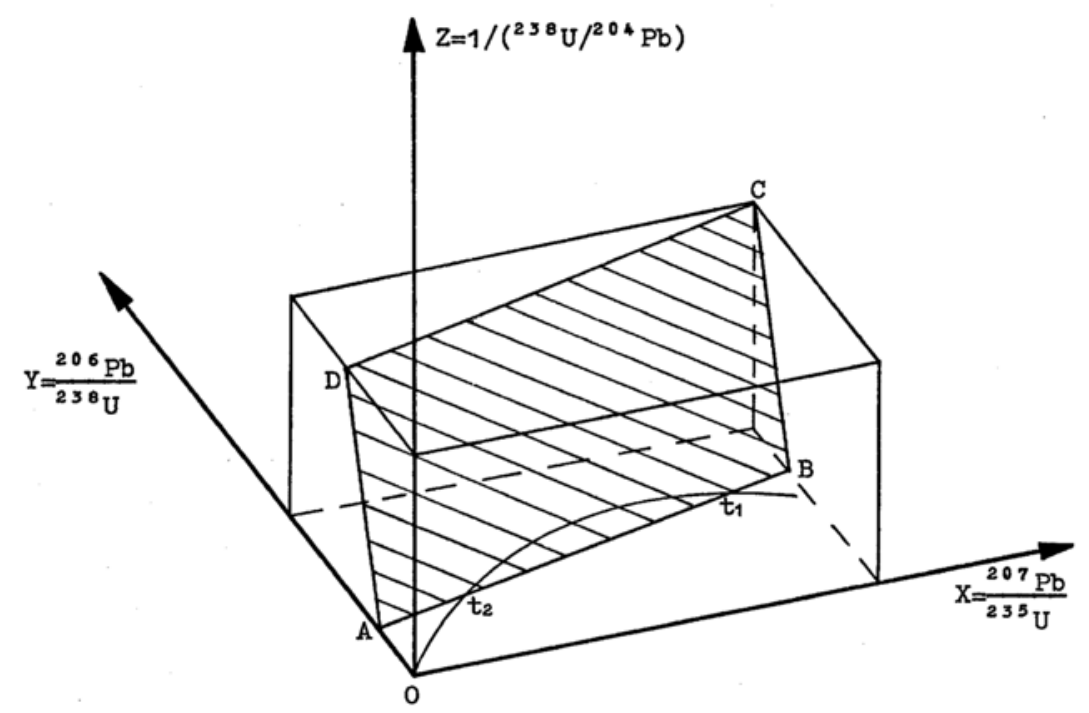

Fig. 1. U-Pb discordia plane diagram. Line $A B$ is in the ${ }^{206} \mathrm{~Pb} /{ }^{238} \mathrm{U}$ versus ${ }^{207} \mathrm{~Pb} /{ }^{235} \mathrm{U}$ plane.

a check of the assumptions that all of the specimens have evolved in the two-stage model and remained closed to uranium and lead. Graphically a diagram of $\left({ }^{206} \mathrm{~Pb} /{ }^{238} \mathrm{U}\right)$ p $-a_{3} /\left({ }^{238} \mathrm{U} /{ }^{204} \mathrm{~Pb}\right)_{\mathrm{p}}$ versus $\left({ }^{207} \mathrm{~Pb} /{ }^{235} \mathrm{U}\right)_{\mathrm{p}}$ can be plotted to display the correlation of the data points.

Geometrically speaking, as shown in Fig. 1, the transformation of Eq. (1) into Eq. (5) is equivalent to constructing a discordia plane $\mathrm{ABCD}$ that cuts the ${ }^{206} \mathrm{~Pb} /{ }^{238} \mathrm{U}$ versus ${ }^{207} \mathrm{~Pb} /{ }^{235} \mathrm{U}$ plane along a straight line $\mathrm{AB}$ whose equation corresponds to Wetherill's discordia equation. The condition $1 /\left({ }^{238} \mathrm{U} /{ }^{204} \mathrm{~Pb}\right)=0$ implies that the specimens did not contain the common lead.

\section{Pb-Pb Isochron Plane Model}

Physically the usual form of the two-stage model equation has been given by Gale and Mussett (1973):

$$
\begin{aligned}
\left(\frac{{ }^{206} \mathrm{~Pb}}{{ }^{204} \mathrm{~Pb}}\right)_{\mathrm{p}}= & \left(\frac{{ }^{206} \mathrm{~Pb}}{{ }^{204} \mathrm{~Pb}}\right)_{\mathrm{i}}+\left(\frac{{ }^{238} \mathrm{~Pb}}{{ }^{204} \mathrm{~Pb}}\right)_{2}\left(\exp \lambda t_{1}-\exp \lambda t_{2}\right) \\
& +\left(\frac{{ }^{238} \mathrm{U}}{{ }^{204} \mathrm{~Pb}}\right)_{3}\left(\exp \lambda t_{2}-1\right) \\
\left(\frac{{ }^{207} \mathrm{~Pb}}{{ }^{204} \mathrm{~Pb}}\right)_{\mathrm{p}}= & \left(\frac{{ }^{207} \mathrm{~Pb}}{{ }^{204} \mathrm{~Pb}}\right)_{\mathrm{i}}+\frac{1}{137.88}\left(\frac{{ }^{238} \mathrm{U}}{{ }^{204} \mathrm{~Pb}}\right)_{2}
\end{aligned}
$$

$$
\begin{aligned}
& \times\left(\exp \lambda^{\prime} t_{1}-\exp \lambda^{\prime} t_{2}\right) \\
& +\frac{1}{137.88}\left(\frac{{ }^{238} \mathrm{U}}{{ }^{204} \mathrm{~Pb}}\right)_{3}\left(\exp \lambda^{\prime} t_{2}-1\right)
\end{aligned}
$$

where the subscripts 2 and 3 denote the time $t_{2}$ and the present-day, respectively. In order to preserve consistency with the U-Pb discordia plane model in numbering the stages of episodic $\mathrm{U}-\mathrm{Pb}$ evolution, it is taken in this section that Eq. (7) still refers to the two-stage model because it involves only two episodic differentiations of uranium relative to lead. Actually it corresponds to a three-stage model equation described by Gale and Mussett (1973). In this regard a further discussion has been given by Chu (1975).

An expression for $\left({ }^{238} \mathrm{U} /{ }^{204} \mathrm{~Pb}\right)_{2}$ can be derived from Eq. (7a) and then substituted into Eq. (7b). We thus obtain another form of plane equation:

$$
\left(\frac{{ }^{207} \mathrm{~Pb}}{{ }^{204} \mathrm{~Pb}}\right)_{\mathrm{p}}=b_{1}\left(\frac{{ }^{206} \mathrm{~Pb}}{{ }^{204} \mathrm{~Pb}}\right)_{\mathrm{p}}+b_{2}\left(\frac{{ }^{238} \mathrm{~Pb}}{{ }^{204} \mathrm{~Pb}}\right)_{\mathrm{p}}+b_{3}
$$

in which

$$
\begin{aligned}
& b_{1}=\frac{\exp \lambda^{\prime} t_{1}-\exp \lambda^{\prime} t_{2}}{137.88\left(\exp \lambda t_{1}-\exp \lambda t_{2}\right)} \\
& b_{2}=\frac{1}{137.88}\left(\exp \lambda^{\prime} t_{2}-1\right)-b_{1}\left(\exp \lambda t_{2}-1\right)
\end{aligned}
$$




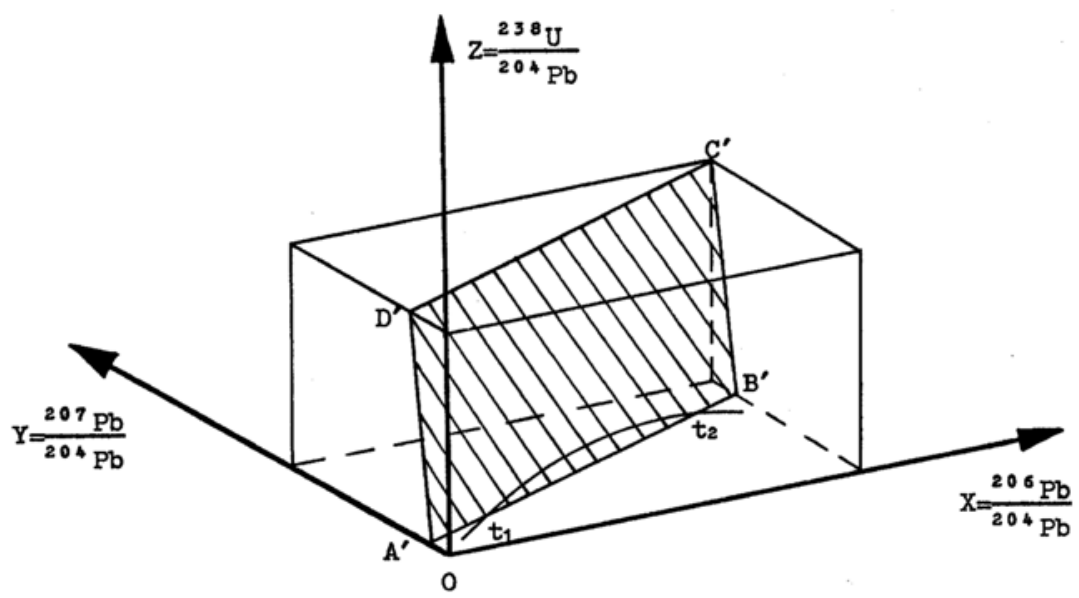

Fig. 2. $\mathrm{Pb}$-Pb isochron plane diagram. Line $\mathrm{A}^{\prime} \mathrm{B}^{\prime}$ is in the ${ }^{207} \mathrm{~Pb} /{ }^{204} \mathrm{~Pb}$ versus ${ }^{206} \mathrm{~Pb} /{ }^{204} \mathrm{~Pb}$ plane.

$$
b_{3}=\left(\frac{{ }^{207} \mathrm{~Pb}}{{ }^{204} \mathrm{~Pb}}\right)_{\mathrm{i}}-b_{1}\left(\frac{{ }^{206} \mathrm{~Pb}}{{ }^{204} \mathrm{~Pb}}\right)_{\mathrm{i}}
$$

A similar form to Eq. (8) was derived by Neymark and Levchenkov (1979), but there is an incorrect expression for the term $b_{3}$ in their Eq. (3).

Within the framework of this model, as depicted in Fig. 2, a suite of cogenetic samples will lie on the plane $A^{\prime} B^{\prime} C^{\prime} D^{\prime}$ which cuts the ${ }^{207} \mathrm{~Pb} /{ }^{204} \mathrm{~Pb}$ versus ${ }^{206} \mathrm{~Pb} /{ }^{204} \mathrm{~Pb}$ plane along $\mathrm{a}$ straight line $\mathrm{A}^{\prime} \mathrm{B}^{\prime}$ which intersects the $\mathrm{Pb}-\mathrm{Pb}$ growth curve at $t_{1}$ and $t_{2}$, respectively. The condition ${ }^{238} \mathrm{U} /{ }^{204} \mathrm{~Pb}=0$ means that there would not exist measurable uranium in the analysed samples.

Because the quantities $\left({ }^{207} \mathrm{~Pb} /{ }^{204} \mathrm{~Pb}\right)_{\mathrm{p}}$, $\left({ }^{206} \mathrm{~Pb} /{ }^{204} \mathrm{~Pb}\right)_{\mathrm{p}}$ and $\left({ }^{238} \mathrm{U} /{ }^{204} \mathrm{~Pb}\right)_{\mathrm{p}}$ can be directly measured, least squares fitting applied to Eq. (8) yields $b_{1}, b_{2}$ and $b_{3}$ from which $t_{1}$ and $t_{2}$ can be derived without a correction for common lead. Not only can the polycorrelation coefficient $R$ serve as a check of the assumptions; graphically the goodness of fit of the data points can be shown on a diagram of $\left({ }^{207} \mathrm{~Pb} /{ }^{204} \mathrm{~Pb}\right)_{\mathrm{p}}$ $-b_{2}\left({ }^{238} \mathrm{U} /{ }^{204} \mathrm{~Pb}\right)_{\mathrm{p}}$ versus $\left({ }^{206} \mathrm{~Pb} /{ }^{204} \mathrm{~Pb}\right)_{\mathrm{p}}(\mathrm{Chu}, 1975)$.

A modified U-Pb discordia plane model can be obtained by dividing Eq. (8) by $\left({ }^{206} \mathrm{~Pb} /{ }^{204} \mathrm{~Pb}\right)_{\mathrm{p}}$, giving the following form:

$$
\left(\frac{{ }^{207} \mathrm{~Pb}}{{ }^{206} \mathrm{~Pb}}\right)_{\mathrm{p}}=b_{1}+b_{2}\left(\frac{{ }^{238} \mathrm{U}}{{ }^{206} \mathrm{~Pb}}\right)_{\mathrm{p}}+b_{3} /\left(\frac{{ }^{206} \mathrm{~Pb}}{{ }^{204} \mathrm{~Pb}}\right)_{\mathrm{p}}
$$

which was derived by Wendt (1984) in another way. Geometrically speaking, this operation is equivalent to constructing the modified discordia plane which cuts the ${ }^{207} \mathrm{~Pb} /{ }^{206} \mathrm{~Pb}$ versus ${ }^{238} \mathrm{U} /{ }^{206} \mathrm{~Pb}$ plane along a straight line whose equation corresponds to the modified discordia equation of Tera and Wasserburg (1972). The condition $1 /\left({ }^{206} \mathrm{~Pb} /{ }^{204} \mathrm{~Pb}\right)=0$ indicates that the samples did not contain the common lead.

\section{Examples and Conclusions}

Purely as a way of illustrating the threedimensional method, a computer programme has been used with data published in the literature for seven suites of samples. These include zircons from the pre-Permian basements of the Bohemian Massif (Grauert et al., 1973), from the Precambrian Fay-de-Bretagne eclogite in the Hercynian belt of South Brittany (Paquette et al., 1985), from acidic porphyritic volcanites of Mareuil-sur-Lay Formation in the Armorican Massif (Peucat et al., 1986) and from Hushan granite of the Taishan complex, China (Jahn et al., 1988), and uranium minerals such as primary pitchblende from Ace Mine, Saskatchewan (Russell and Ahrens, 1957) and secondary torbernite from the uranium mineralization in the basement rocks at Grosschloppen, NE Bavaria (Carl and Dill, 1985), as well as a meteorite (Unruh et al., 1979). As shown in 
Table 1. Some examples using the three-dimensional method

\begin{tabular}{|c|c|c|c|c|c|c|c|c|c|c|c|}
\hline \multirow{2}{*}{ Occurrence } & \multirow{2}{*}{ Mineral } & \multirow{2}{*}{$\begin{array}{c}\text { Number } \\
\text { of } \\
\text { sample }\end{array}$} & \multicolumn{2}{|c|}{$\begin{array}{l}\text { U-Pb discordia } \\
\text { plane model }\end{array}$} & \multicolumn{2}{|c|}{$\begin{array}{l}\mathrm{Pb}-\mathrm{Pb} \text { isochron } \\
\text { plane model }\end{array}$} & \multicolumn{2}{|c|}{$\begin{array}{c}\text { Modified U-Pb } \\
\text { dis-cordia plane } \\
\text { model }\end{array}$} & \multicolumn{2}{|c|}{$\begin{array}{l}\text { Usual concordia } \\
\text { diagram }\end{array}$} & \multirow{2}{*}{ References } \\
\hline & & & $t_{2}(\mathrm{Ma})$ & $t_{1}(\mathrm{Ma})$ & $t_{2}(\mathrm{Ma})$ & $t_{1}(\mathrm{Ma})$ & $t_{2}(\mathrm{Ma})$ & $t_{1}(\mathrm{Ma})$ & $t_{2}(\mathrm{Ma})$ & $t_{1}(\mathrm{Ma})$ & \\
\hline $\begin{array}{l}\text { Bohemian } \\
\text { Massif }\end{array}$ & zircon & 18 & 564 & 2263 & 562 & 2254 & 565 & 2251 & 560 & 2260 & $\begin{array}{l}\text { Grauert et al. } \\
\text { (1973) }\end{array}$ \\
\hline Brittany & zircon & 6 & 410 & 2169 & 401 & 2113 & 406 & 2148 & 413 & 2208 & $\begin{array}{l}\text { Paquette et al. } \\
\text { (1985) }\end{array}$ \\
\hline $\begin{array}{l}\text { Armorican } \\
\text { Massif }\end{array}$ & zircon & 6 & 397 & 2108 & 385 & 2121 & 396 & 2083 & 392 & 2103 & $\begin{array}{l}\text { Peucat et al. } \\
\text { (1986) }\end{array}$ \\
\hline Taishan & zircon & 10 & 347 & 2560 & 327 & 2556 & 344 & 2560 & 334 & 2560 & $\begin{array}{l}\text { Jahn et al. } \\
\text { (1988) }\end{array}$ \\
\hline Ace Mine & pitchblende & 5 & 252 & 1781 & 163 & 1813 & 231 & 1764 & 190 & 1800 & $\begin{array}{l}\text { Russell and } \\
\text { Ahrens (1957) }\end{array}$ \\
\hline Bavaria & torbernite & 8 & 6.4 & 244 & 5.7 & 218 & 5.9 & 225 & 5.2 & 205 & $\begin{array}{l}\text { Carl and Dill } \\
\text { (1985) }\end{array}$ \\
\hline Barwell & chondrite & 10 & -53 & 4530 & -91 & 4549 & -176 & 4541 & -170 & 4536 & $\begin{array}{l}\text { Unruh et al. } \\
\text { (1979) }\end{array}$ \\
\hline
\end{tabular}

Table 1, the age values obtained applying the present methods agree well with the results given by the concordia diagram. Therefore, the threedimensional U-Pb method can yield the $t_{1}$ and $t_{2}$ ages in the case of a two-stage evolution history without any assumption about the isotopic composition of the common lead present in the $\mathrm{U}-\mathrm{Pb}$ system of the samples being investigated.

The U-Pb discordia plane model and the $\mathrm{Pb}$ $\mathrm{Pb}$ isochron plane model described in the present paper are not independent of each other. Theoretically a suite of cogenetic samples will yield identical results for the three types of 3dimensional'solution if the mathematical treatments are correct and the sample system being investigated did experience the two-stage evolution. In this context there is no reason to prefer one or the other type of presentation. In setting about the task of interpreting a given set of $\mathrm{U}-\mathrm{Pb}$ data one can nevertheless treat the U-Pb data by the three 3-dimensional models together to check all of the required isotopic information, e.g. not only the ages of the two episodic events, but also the "real" isotope ratios of the initial (common) lead through Eq. (6) or (11). Furthermore, the $\mathrm{Pb}-\mathrm{Pb}$ isochron plane model can possibly treat a suite of samples with relatively high amounts of initial lead, or with very low uranium content, which makes it impossible to use the usual concordia diagram approach.
Acknowledgments-I wish to thank Profs. Yu-Liang Xia and Quan Tao for introducing me to the basic principles of $\mathrm{U}-\mathrm{Pb}$ multistage models. I am indebted to Profs. N. H. Gale and C. J. Hawkesworth for their constructive comments.

\section{REFERENCES}

Carl, C. and Dill, H. (1985) Age of secondary uranium mineralization in the basement rocks of northeastern Bavaria, F.R.G. Isot. Geosci. 3, 295316.

Chu, Ping-Chuan (1975) A contribution to the threestage model of $\mathrm{U}-\mathrm{Pb}$ isotopic system. Geochimica No. 2, 123-134 (Chinese with English abstract).

Gale, N. H. and Mussett, A. E. (1973) Episodic uranium-lead models and the interpretation of variations in the isotopic composition of lead in rocks. Rev. Geophys. Space Phys. 11, 37-86.

Grauert, B., Hänny, R. and Soptrajanova, G. (1973) Age and origin of detrital zircons from pre-Permian basements of the Bohemian Massif and the Aips. Contrib. Mineral. Petrol. 40, 105-130.

Jahn, B. M., Auvray, B., Shen, Q. H., Liu, D. Y., Zhang, Z. Q., Dong, Y. J., Ye, X. J., Zhang, Q. Z., Cornichet, J. and Mace, J. (1988) Archean crustal evolution in China: the Taishan complex, and the evidence for juvenile crustal addition from long-term depleted mantle. Precambrian Res. 38, 381-403.

Levchenkov, O. A. and Shukolyukov, Yu. A. (1970) A new method for calculating age and time of metamorphism of minerals and rocks without correction for ordinary lead. Geokhimiya (Translation) No. 1, 88-95. 
Ludwig, K. R., Wallace, A. R. and Simmons, K. R. (1985) The Schwartzwalder uranium deposit, II: age of uranium mineralization and lead isotope constraints on genesis. Econ. Geol. 80, 1858-1871.

Neymark, L. A. and Levchenkov, O. A. (1979) A method of age calculation for open U-Pb isotope systems. Geokhimiya (Translation) No. 5, 686-692.

Paquette, J. L., Peucat, J-J., Bernard-Griffitns, J. and Marchand, J. (1985) Evidence for old Precambrian relics shown by U-Pb zircon dating of eclogites and associated rocks in the Hercynian belt of South Brittany, France. Isot. Geosci. 3, 203-216.

Peucat, J-J., Paris, F. and Chalet, M. (1986) U-Pb zircon dating of volcanic rocks, close to the SilurianDevonian boundary, from Vendée (western France). Isot. Geosci. 5, 133-142.

Russell, R. D. and Ahrens, L. H. (1957) Additional Regularities among discordant lead-uranium ages. Geocheim. Cosmochim. Acta 11, 213-218.

Tera, F. and Wasserburg, G. J. (1972) U-Th-Pb systematics in three Apollo 14 basalts and the problem of initial $\mathrm{Pb}$ in lunar rocks. Earth Planet. Sci. Lett. 14, 281-304.

Unruh, D. M., Hutchison, R. H. and Tatsumoto, M. (1979) U-Th- $\mathrm{Pb}$ age of the Barwell chondrite: Anatony of a "discordant" meteorite. Proc. Lunar Planet. Sci. Conf. 10th, 1011-1030.

Wendt, I. (1984) A three-dimensional U-Pb discordia plane to evaluate samples with common lead of unknown isotopic composition. Isot. Geosci. 2, 112.

Wetherill, G. W. (1956) Discordant uranium-lead ages, I. Trans. Am. Geophys. Union 37, 320-326.

\section{APPENDIX}

\section{Least Squares Fitting of Plane Equation}

For a plane equation:

$$
y=a x+c z+b
$$

the simplest method of fitting data points is the least squares regression procedure, which consists of minimizing the sum of the squares of the difference between the observed and calculated values, i.e.

$$
\Sigma\left(y_{\text {obs }}-y_{\text {calc }}\right)^{2}=\text { minimum. }
$$

Given the constants $a, b, c$, we can for any given point $(x, z)$ calculate:

$$
y_{\text {calc }}=a x+c z+b
$$

and the deviation between $y_{\text {obs }}$ and $y_{\text {calc }}$ is given by

$$
\text { deviation }=y_{\mathrm{obs}}-a x-c z-b .
$$

If the sum of the squared deviations is given by $F(a, b, c)$, then

$$
F(a, b, c)=\Sigma\left(y_{\mathrm{obs}}-a x-c z-b\right)^{2} .
$$

If $F(a, b, c)$ is to be minimized, then the partial differentials should equal zero:

$$
\frac{\partial F}{\partial a}=\frac{\partial F}{\partial b}=\frac{\partial F}{\partial c}=0
$$

using the values of $y_{\mathrm{obs}}$, the partial derivations are

$$
\begin{aligned}
& \frac{\partial F}{\partial a}=\Sigma 2(y-a x-c z-b)(-x)=0 \\
& \frac{\partial F}{\partial b}=\Sigma 2(y-a x-c z-b)(-1)=0 \\
& \frac{\partial F}{\partial c}=\Sigma 2(y-a x-c z-b)(-z)=0
\end{aligned}
$$

which, on multiplying out and summing the individual terms, gives

$$
\begin{aligned}
& a \sum x^{2}+c \sum x z+b \sum x=\sum x y \\
& a \sum x+c \sum z+n b=\sum y \\
& a \sum x z+c \sum z^{2}+b \sum z=\Sigma y z
\end{aligned}
$$

where $n=$ the number of data points and the summation signs imply summing from 1 to $n$. The equations for calculating the parameters $(a, b$ and $c$ ) of the best plane are:

$$
\begin{aligned}
& a=\frac{W_{x y} W_{z^{2}}-W_{y z} W_{x z}}{W_{x^{2}} W_{z^{2}}-W_{x z} W_{x z}} \\
& c=\frac{W_{y z} W_{x^{2}}-W_{x y} W_{x z}}{W_{x^{2}} W_{z^{2}}-W_{x z} W_{x z}} \\
& b=\bar{y}-a \bar{x}-c \bar{z}
\end{aligned}
$$

in which

$$
\begin{aligned}
& \bar{x}=\frac{1}{n} \sum x, \bar{y}=\frac{1}{n} \sum y, \bar{z}=\frac{1}{n} \sum z \\
& W_{x^{2}}=\sum(x-\bar{x})^{2}, W_{z^{2}}=\Sigma(z-\bar{z})^{2} \\
& W_{x y}=\sum(x-\bar{x})(y-\bar{y})
\end{aligned}
$$


$W_{x z}=\Sigma(x-\bar{x})(z-\bar{z})$

$W_{y z}=\Sigma(y-\bar{y})(z-\bar{z})$.

The polycorrelation coefficient is given by

$$
R=\sqrt{1-\frac{F}{\sum(y-\bar{y})^{2}}} \quad(0 \leq R \leq 1)
$$

A pocket computer is sufficient to perform the planar regression. The more exact method of calculating the parameters of the best plane must take into account the known analytical errors of the coordinates of the data points on the plane diagram. This can be accomplished by the use of weighting residuals, which has been given by Wendt (1984). 